\title{
LAYER-BY-LAYER GROWTH OF CERAMICS THIN FILMS AND ITS IMPLICATION IN THE EXPLORATION OF NEW HIGH T。SUPERCONDUCTORS
}

\section{セラミックス薄膜の層状成長と新高温超伝導体の研究}

Hideomi KOINUMA

Research Laboratory of Engineering Materials, Tokyo Institute of Technology 4259 Nagatsuta, Midori-ku, Yokohama 227, Japan.

TEL. 045-922-1111 ext. 2353, FAX. 045-921-1015

(Recieved 27, November 1990)

(Accepted 31, January 1991)

In view of the common features of high $\mathrm{T}_{\circ}$ superconducting materials, such as very short coherence length and layered perovskite structure, sophiscated ceramics thin film technology is expected to be a powerful tool for fabricating Josephson tunnel junction devices as well as for constructing artificially designed new ceramics layers which may exhibit still higher $T_{c}$ superconductivity. Studies on the epitaxial growth of ceramics films relating to high $T_{0}$ superconductors are reported with a focus placed on our recent research using a pulsed laser deposition in ultra-high vacuum system (laser MBE).

Keywords: high $\mathrm{T}_{\circ}$, ceramics, MBE, epitaxial growth, tunnel junction

\section{Introduction}

Cuprates with high $\mathrm{T}_{\circ}$ superconductivity attract our special interest not only because they may provide remarkable progress in electronics devices but also because they could promote a new research on physics and chemistry of ceramics superlattices. High $\mathrm{T}_{\text {。 }}$ cuprates commonly have layered perovskite structures which contain square-planar $\mathrm{CuO}_{2}$ lattices spreading normal to the c lattice. This layered structure is considered to be closely related with the realization of high $\mathrm{T}$ 。 superconductivity. From analogy to semiconductor superlattices, it should be of primary importance to establish a technology of layer-by-layer growth various kinds of ceramics with each layer thickness regulated on an atomic scale for constructing new ceramics superlattices which may exhibit a quantum effect including high $\mathrm{T}_{\circ}$ superconductivity. The same technology could also be very useful for fabricating tunnel (SIS) type Josephson junctions, since very short coherence lengths in high $\mathrm{T}_{\circ}$ oxide $(\mathrm{S})$ should require atomic scale control in the formation of insulative oxide (I) layer. Despite many reports on layer-by-layer deposition of high $\mathrm{T}_{0}$ superconducting films by such methods as multitarget sputtering 1,2), laser deposition 3-6), and conventional molecular beam epitaxy (MBE) 7), there have been scantly reported in situ analysis on the growth manner and interface structure of the layers.

2. Systematic Analysis of layered Structures in High $\mathrm{T} \circ$ Superconductors 
Let me first analyze the basic components of high $\mathrm{T}_{\circ}$ cuprates to get a clue for designing possible new superconducting materials. Since high $\mathrm{T}_{\mathrm{c}}$ superconductors have layered perovskite structures, we can expect the possibility of constructing the same structures by piling up the subunit layers along the c-axis. The subunit layers could be divided to three types; a $\left(\mathrm{CuO}_{z}\right)^{2-}$ layer working as a conductive layer, a coupling layer always sandwiched by two $\left(\mathrm{CuO}_{2}\right)^{2-}$ layers, and a blocking layer composed of more than two atomic layers of oxides and separating two $\left(\mathrm{CuO}_{2}\right)^{2-}$ layers. The lattice of $\mathrm{Bi}_{2} \mathrm{Sr}_{2} \mathrm{CaCu}_{2} \mathrm{O}_{8}$, for example, is constructed from a $\left(\mathrm{SrO}-\mathrm{Bi}_{2} \mathrm{O}_{2}-\mathrm{SrO}\right)^{2+}$ blocking layer, a $\left(\mathrm{CuO}_{2}\right)^{2-}$ layer, a $\mathrm{Ca}^{2+}$ coupling layer, and another $\left(\mathrm{CuO}_{z}\right)^{2-}$ layer, respectively. This three elementary sublayers model is valid not only for constructing the already discovered high $\mathrm{T}_{\mathrm{c}}$ superconductors but also for providing us an idea to design new superconductors. As shown in Table I, there are a lot of combinations of blocking and coupling layers to be explored for the possibility of new layered structures. One of these new materials, $(\mathrm{La}, \mathrm{Sr})_{2} \mathrm{CaCu}_{2} \mathrm{O}_{6}$, was discovered recently by Cava et al 8).
In order to construct such new structures, atomically regulated layer-by-layer technique should be developed. The deposition unit layers may be different from the constitutional sublayers described above, since the sublayers are frequently charged and would not be stably grown by themselves. A charged sublayer can be combined with the adjacent atomic layer(s) to from neutral deposition unit.

3. Layer-by-Layer Deposition by Conventional Multi-sources PVD

Since $\mathrm{Tc}$ of $\mathrm{M}_{2} \mathrm{M}_{2}{ }_{2} \mathrm{Ca}_{n-1} \mathrm{Cu}_{n} \mathrm{O} \times\left(\mathrm{M}=\mathrm{Bi}, \mathrm{Tl} ; \mathrm{M}^{\prime}\right.$ $=\mathrm{Sr}, \mathrm{Ba})$ increased as the number $(\mathrm{n})$ of $\mathrm{CuO}_{2}$ layer(s) in the unit cell increased from 1 to 3 , further $T_{c}$ increase was expected in the compounds with higher number of $n$. Due to the probable themodynamical instabibty in these compounds of $n \geqq 4$, bulk sintering method has not produced these compounds in the single phase. Thin film deposition from the gas phase is a kind of non-equilibrium process and could isolate such a compound even if it is in a metastable phase. Table II summarizes the studies on layer-by-layer deposition approach to new superconductors 9). Primarily, multi-targets sputtering and laser ablation

Table I Possible combination of blocking and coupling layers for constructing HTSC related structures.

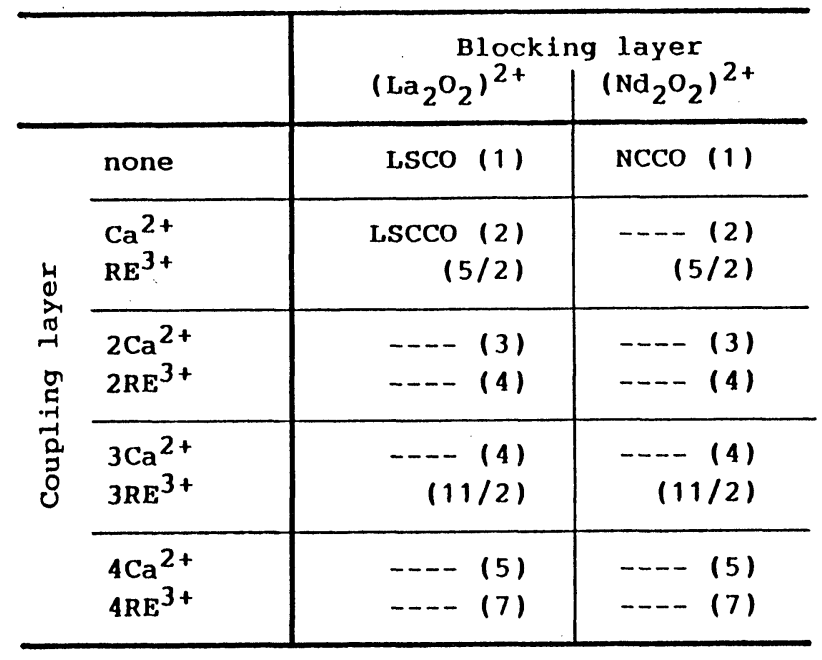


Table II Attempts for depositing multi-layered ceramic films related to high $\mathrm{T}$ 。

superconductors.

\begin{tabular}{|c|c|c|c|c|c|}
\hline $\begin{array}{l}\text { Preparation } \\
\text { method }\end{array}$ & $\begin{array}{l}\text { Source } \\
\text { (Temp. of } \\
\text { substrate) }\end{array}$ & $\begin{array}{l}\text { Layer- } \\
\text { controlling } \\
\text { system }\end{array}$ & $\begin{array}{l}\text { Tc } \\
\text { as- } \\
\text { grown }\end{array}$ & $\begin{array}{l}(\mathrm{K}) \\
\left(\mathrm{CuO}_{2}\right) \mathrm{n} \\
\text { annealed. }\end{array}$ & Reinarks \\
\hline rf-sputter & $\mathrm{Y} / \mathrm{Ba} / \mathrm{Cu}$ & shutter & & & $\begin{array}{l}\text { in situ } \\
\text { XPS }\end{array}$ \\
\hline rf-sputter & $\begin{array}{l}\mathrm{B1} / \mathrm{SrCu} / \\
\mathrm{CaCu} / \mathrm{SrCu} \\
\left(680^{\circ} \mathrm{C}\right)\end{array}$ & shutter & $\begin{array}{l}10- \\
90\end{array}$ & $\begin{array}{l}n=2 ; 80 \\
n=3 ; 110 \\
n=4 ; 90\end{array}$ & $\begin{array}{l}\left(\mathrm{CuO}_{2}\right)_{4} \\
\text { layer }\end{array}$ \\
\hline rf-sputter & $\begin{array}{l}\mathrm{Bi} / \\
\mathrm{Sr}_{2} \mathrm{Ca}_{2} \mathrm{Cu}_{2} \mathrm{O}_{x} \\
\left(650^{\circ} \mathrm{C}\right)\end{array}$ & shutter & $\begin{array}{c}90 \\
\text { (onset) }\end{array}$ & & \\
\hline$r f$-sputter & $\begin{array}{l}\text { BiSro }{ }^{\prime} \\
\text { CaCuOy } \\
\text { (RT) }\end{array}$ & $\begin{array}{l}\text { plasma- } \\
\text { controll }\end{array}$ & ins. & $n=3 ; \quad 75$ & $\begin{array}{l}\text { selective } \\
\text { sputter }\end{array}$ \\
\hline $\begin{array}{l}\text { laser- } \\
\text { ablation }\end{array}$ & $\begin{array}{l}\mathrm{Bi}_{2} \mathrm{O}_{3} \\
\left(\mathrm{Bi}_{7} \mathrm{~Pb}_{3} \mathrm{O}_{Y}\right)^{\prime} \\
\left./ \mathrm{SrCuO}_{Y}\right)^{-} \\
\mathrm{CaCuO} \\
\left(450-600^{\circ} \mathrm{C}\right)\end{array}$ & $\begin{array}{l}\text { changing } \\
\text { target }\end{array}$ & ins. & $\begin{array}{l}n=1 \\
-5 ;<40\end{array}$ & $\begin{array}{l}\mathrm{N}_{2} \mathrm{O} \text {-gas } \\
\text { anneal }\end{array}$ \\
\hline $\begin{array}{l}\text { ion beam } \\
\text { sputter }\end{array}$ & $\begin{array}{l}\mathrm{Bi}_{2} \mathrm{O}_{3} / \\
\mathrm{Sr}_{2} \mathrm{Ca}_{2} \mathrm{Cu}_{3} \mathrm{O}_{x} \\
\left(65^{\circ} \mathrm{C}\right)\end{array}$ & shutter & 45 & & $\begin{array}{l}\text { in situ } \\
\text { RHEED }\end{array}$ \\
\hline $\begin{array}{l}\text { electron } \\
\text { beam eva- } \\
\text { poration }\end{array}$ & $\begin{array}{l}\mathrm{Dy} / \mathrm{Ba} / \mathrm{Cu} \\
\left(000^{\circ} \mathrm{C}\right)\end{array}$ & shutter & 60 & & $\begin{array}{l}\text { in situ } \\
\text { RHEED }\end{array}$ \\
\hline $\begin{array}{l}\text { electron } \\
\text { beam + } \\
\text { thermal } \\
\text { evaporation }\end{array}$ & $\begin{array}{l}\mathrm{Y} / \mathrm{Ba} / \mathrm{Cu} \\
\left(600^{\circ} \mathrm{C}\right)\end{array}$ & shutter & 82 & & $\begin{array}{l}\text { in situ } \\
\text { RHEED }\end{array}$ \\
\hline $\begin{array}{l}\text { electron } \\
\text { beam eva- } \\
\text { poration }\end{array}$ & $\begin{array}{l}\mathrm{Y} / \mathrm{BaF}_{2} / \\
\mathrm{Cu} \\
\left(450^{\circ} \mathrm{C}\right)\end{array}$ & shutter & lns. & $90 \mathrm{~K}$ & $\begin{array}{l}a-a \times 1 s \\
\text { ortent. }\end{array}$ \\
\hline $\begin{array}{l}\text { thermal } \\
\text { evaporation }\end{array}$ & $\begin{array}{l}\mathrm{T} 1 / \mathrm{BaCaCu} \\
(\mathrm{RT})\end{array}$ & shutter & ins. & $85 \mathrm{~K}$ & $\begin{array}{l}\text { Tl-vapor } \\
\text { anneal }\end{array}$ \\
\hline
\end{tabular}

methods were employed and deposited films were post-annealed to improve the crystalinity and superconductivity. By substituting an element in one of the targets, we can selectively substitute a component in the superconductors. The multilayered films thus prepared to date have not exceeded the highest Tc (125K) so far reported in bulk superconductors.

When a superconducting $(\mathrm{S})$ and a non-superconducting (N) targets were sputtered or ablated alternatingly, multilayered $\left[\mathrm{S}_{\mathrm{a}} \mathrm{N}_{\mathrm{b}}\right]_{\mathrm{n}}$ films, such as $\left[(\mathrm{YBCO})_{a} /(\mathrm{PrBCO})_{b}\right]_{n}$, could be prepared. The superconductivity observed in the films even with $\mathrm{a}=1$ indicates that the unit c lattice (ca. $12 \mathrm{~A}$ ) is thick enough for the superconductivity in YBCO.

4. UHV Layer-by-Layer Deposition with in situ Surface Analysis

Most of the layer-by-layer deposition processes described above were performed without in situ surface monitoring and accompanied by high temperature post anneating. Hence, it is hard to employ these processes for making artificially designed new layered lattices such as those suggested in Table I. We need more advanced technology for depositing digitally ( $\sim 2 \mathrm{~A}$ ) controlled epitaxial layers and for minimizing interdiffusion at the interface. It will be requested for this purpose to develop a two dimensional layer-by-layer growth technique.

For the verification of this ceramics layer epitaxy technique, observation of RHEED intensity oscillation during the deposition is essential as it is in the case of semiconductor growth by conventional MBE. Another key technology for oxide film epitaxy is the control of oxidation state in the as-grown film. In general, ultra-high vacuum (UHV) atmosphere $\left(<10^{-8}\right.$ Torr) and high substrate temperature $\left(300-800^{\circ} \mathrm{C}\right)$ applied in the conventional MBE system are favorable for two dimensional 
epitaxial growth, but are thermodynamically unfavorable for incorporating sufficient oxygen (hole) in the film. This contradictory condition, oxidation in UHV, could be compromised by the use of highly reactive oxidants 7), 10).

Schnom et al. used pure ozone as oxidant for conventional MBE growth of $\mathrm{Bi}_{2} \mathrm{Sr}_{2} \mathrm{Ca}_{n-1} \mathrm{Cu}_{n} \mathrm{O}_{\times}$ by iterating the sequential oxidative evaporations of $\mathrm{Bi}, \mathrm{SrCu}$, and $\mathrm{CaCu}$ metals 7 ). They observed the RHEED intensity oscillation accompanied by the shuttering for controlling the thickness of the depositing layers. The observation of intensity oscillation in streaky RHEED pattern during the contineous growth should strongly indicate that two dimensional eptitaxial growth is going on. From the oscillation period, the thickness of growth unit layer can be determined. This kind of RHEED oscillation was recently detected by Bando's and our research groups. During the deposition of $\mathrm{BaTiO}_{3}, \mathrm{La}_{2} \mathrm{CuO}_{4}$, and $\mathrm{YBa}_{2} \mathrm{Cu}_{3} \mathrm{O}_{\times}$ films by activated evaporation method in the presence of $10^{-5}$ Torr oxygen activated by an ozonizer, Bando et al. observed RHEED oscillation whose periods correspond to the $c$ lattice lengths 11).

We observed RHEED intensity oscillation during the deposition of various ceramics thin films, such as $\mathrm{CeO}_{2}$ and $\mathrm{Nd}_{2} \mathrm{O}_{3}$ on $\mathrm{Si}$ and ( $\mathrm{Sr}$, Ca) $\mathrm{CuO}_{x}$ on $\mathrm{SrTiO}_{3}$, by laser $\mathrm{MBE}$, i.e. pulsed laser deposition in UHV ( $<10^{-8}$ Torr) 12). Some details of our system and results are given below.

Figure 1 illustrates our deposition system connected with an X-ray photoelectron analyzer via a vacuum line $\left(<10^{-8}\right.$ Torr $)$. The system is also equipped with a reflection high energy diffraction (RHEED) and a quadrapole mass spectrometer (QMS). In this laser MBE apparatus, as many as sixteen sintered oxide targets can be ablated with an ArF excimer laser beam in such a way as programmed by a computer to deposit films successively on a heated substrate.

$\mathrm{CeO}_{2}, \mathrm{Nd}_{2} \mathrm{O}_{3}$ and $\left(\mathrm{Sr}_{\times} \mathrm{Ca}_{1-x}\right) \mathrm{CuO}_{2}$ films were deposited on substrates at $600-800^{\circ} \mathrm{C}$ by ablating corresponding sinteredtargets with an

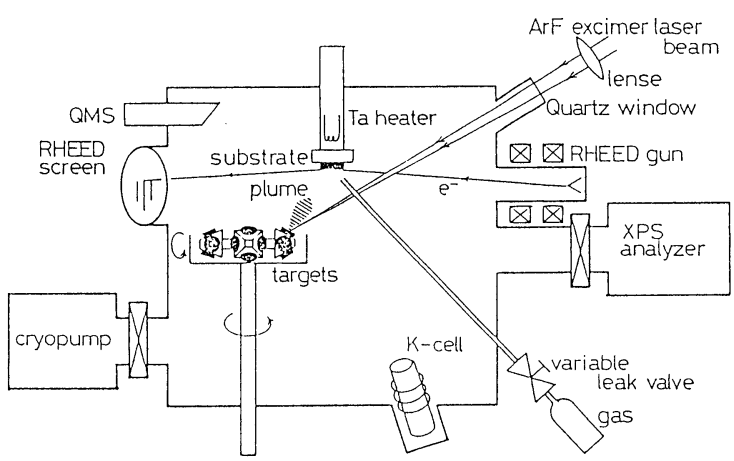

Fig.1. Schematic representation of laser MBE with in situ RHEED and XPS analysers.

ArF excimer laser (about $1 \mathrm{~J} / \mathrm{cm}^{2}, 2 \mathrm{~Hz}$ ). The deposition pressure was kept at mid $-10^{-9}$ Torr during the deposition of $\mathrm{CeO}_{2}$ and $\mathrm{Nd}_{z} \mathrm{O}_{3}$ films on clean $\mathrm{Si}$ (111) surfaces. When $\left(\mathrm{Sr}_{\times} \mathrm{Ca}_{1-x}\right)-\mathrm{CuO}_{2}$ films were deposited on $\mathrm{SrTiO}_{3}$ (001) substrates, $\mathrm{NO}_{2}$ was flushed onto the substrate surface and chamber pressure was kept at $1-2 \times 10^{-7}$ Torr during the deposition and cooling. Distance between the substrate and the $\mathrm{NO}_{z}$ feeder was $20 \mathrm{~mm}$. Deposited films were analyzed in situ by RHEED and XPS. EX situ analysis of films was performed with an X-ray diffractometer (XRD).

Figure 2 shows an intensity variation of the central RHEED streak observed during the

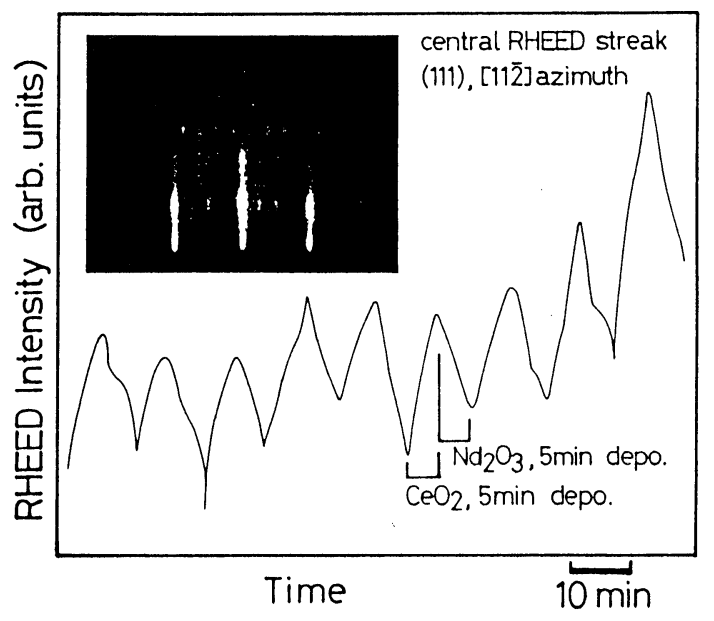

Fig.2. Intensity oscillation depending on the shuttering observed in the formation of $\mathrm{CeO}_{2}(111) / \mathrm{Nd}_{2} \mathrm{O}_{3}$ (111) superlattice on the Si (111) substrate. 
alternating deposition of $\mathrm{CeO}_{2}$ (111) and $\mathrm{Nd}_{2} \mathrm{O}_{3}$ (111) films on Si (111). Although the intensity oscillation due to the two dimensional growth of each unit cell layer was not clear, the oscillation depending on the shuttering was seen clearly. The thickness of the superlattice was measured to be $3.0 \mathrm{~nm}$ by the small angle XRD peak, being in good agreement with the designed thickness of $3.0 \mathrm{~nm}$. $(\mathrm{Sr}, \mathrm{Ca}) \mathrm{CuO}_{z}$ films were deposited on $\mathrm{SrTiO}_{3}$ (001) substrates with $\mathrm{NO}_{z}$ flushing 13 ). Figure 3 shows the intensity oscillation of the central RHEED streak observed during the epitaxial growth of $\left(\mathrm{Sr}_{0.5} \mathrm{Ca}_{\circ .5}\right) \mathrm{CuO}_{2}$ film at $700^{\circ} \mathrm{C}$. The oscillation cycle $(0.33 \mathrm{~nm})$ was very close to the c-axis length $(0.332 \mathrm{~nm})$ of the films measured by XRD. The valence state of $\mathrm{Cu}$ in the as-grown film was evaluated to be $2^{+}$by in situ XPS. The full width at half maximum of rocking curve of (002) XRD peak was $0.43^{\circ}$, indicating a very good crystallinity. Alternating epitaxial growth of $(\mathrm{Sr}, \mathrm{Ca}) \mathrm{CuO}_{2}$ and $(\mathrm{RE})_{2} \mathrm{CuO}_{4}$ layers is now in progress to construct new ceramic superlattices.

\section{Conclusion}

Two-dimensional epitaxial growth of ceramic films in UHV deposition system was confirmed

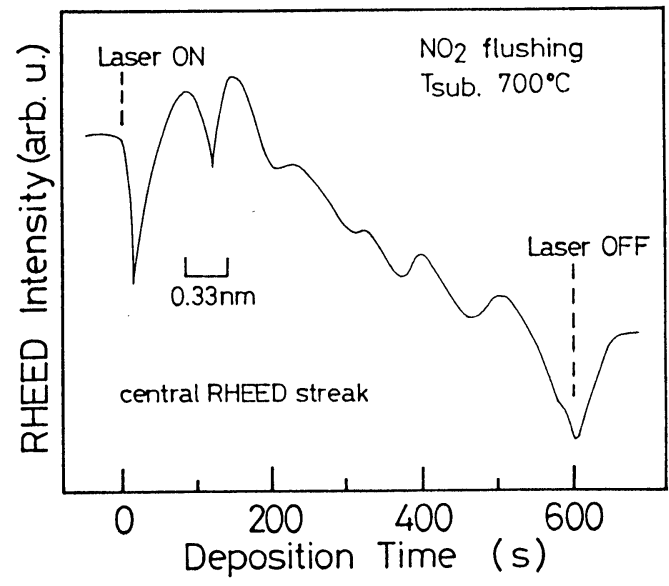

Fig.3. Intensity oscillation of the central RHEED streak observed during the deposition of the $\left(\mathrm{Sr}_{\circ .} \mathrm{Ca}_{\circ .5}\right) \mathrm{CuO}_{z}$ film. The film grew epitaxially with its c-axis normal to the $\mathrm{SrTiO}_{3}(001)$ substrate. to be possible by a few methods including our laser MBE. I hope we can open a new field of ceramics research by developing this "superfine" technology.

\section{REFERENCES}

1. K.Nakamura, J.Sato, M.Kaise, and K.Ogawa, Jpn. J. Appl. Phys., 28 (1989) L437.

2. H.Adachi, S.Kohiki, K.Setsune, T.Mitsuyu, and K.Wasa, Jpn. J. Appl. Phys., 27 (1989) L1883.

3. M.Kanai, T.Kawai, S.Kawai, and H.Tabata, Appl. Phys. Lett., 54 (1989) 1802.

4. M.Kanai, T.Kawai, and S.Kawai, Appl. Phys. Lett., 57 (1990) 198.

5. J.J.Kingston, F.C.Wellstood, P.Lerch, A.H.Miklich, and J.Clarke, Appl. Phys. Lett., 56 (1990) 189.

6. C.T.Rogers, A.Inam, M.S.Hegde, B.Dutta, X.D.Wu, and T.Venkatesan, Appl. Phys. Lett., 55 (1989) 2032

7. D.G.Schlom, A.F.Marshall, J.T.Sizemore, Z.J.Chen, J.N.Eckstein, I.Bozovic, K.E. von Dessonneck, J.S.Harris.Jr., and J.Appl.phys., to be published in J. Crystal Growth.

8. R.J.Cava, B.Batlogg, R.B.van Dover, J.J.Krajewski, J.V.Waszczak, R.M.Fleming, W.F.Perk.Jr., L.W.Rupp.Jr., P.Marsh, A.C.W.P.James, and L.F.Scneemeyer, Nature, 345 (1990) 602.

9. M.Yoshimoto, K.Takeuchi, H.Koinuma, Rept. Res. Lab. Eng. Mater., TIT, 15 (1990) 105.

10. S.Watanabe, M.Kawai, and T.Hanada, Jpn. J. Appl. Phys., 29 (1990) L1111.

11. T.Terashima et al., Phys. Rev. Lett., submitted.

12. H.Koinuma, H.Nagata, T.Tsukahara, S.Gonda, and M.Yoshimoto, Ext. Abst. of the 22nd (1990 Int'l) Conf. on Solid State Devices and Materials, (The Japan Society of Applied Physics), p.933.

13. H.Koinuma et al., Proc. 4th Ann. Conf. on Superconductivity and Application (Buffalo, Sept. 1990), in press.

This paper was presented in the Japan-USSR Joint Symposium at Moscow, Oct. 22, 23, 1990. 